University of Rhode Island

DigitalCommons@URI

Open Access Master's Theses

1954

\title{
A Project in Civic Education in Elementary Schools Through Pupil Participation
}

Mildred Claire Alger

University of Rhode Island

Follow this and additional works at: https://digitalcommons.uri.edu/theses

\section{Recommended Citation}

Alger, Mildred Claire, "A Project in Civic Education in Elementary Schools Through Pupil Participation" (1954). Open Access Master's Theses. Paper 984.

https://digitalcommons.uri.edu/theses/984

This Thesis is brought to you for free and open access by DigitalCommons@URI. It has been accepted for inclusion in Open Access Master's Theses by an authorized administrator of DigitalCommons@URI. For more information, please contact digitalcommons-group@uri.edu. 
A PROJECT IN CIVIC EDUCATT ON IN ELLENENTARY SCHOOLS

THROUGH PUPIL PARTI CI PATI ON

BY

MILDRED CLAIRE ALGER

A THESIS SUBMI TTED IN PARTIAL FULFILLMENT OF THE REQUI REMENTS FOR THE DEGREE OF

MASTER OF SCIENCE

IN

EDUCATI ON

UNIVERSITY OF RHODE ISLAND

1954 


\section{MASTER OF SCIENCE THESIS}

$$
\text { OP }
$$

MI LDRED CLAIRE ALGER

$1 !$

Appreved:

Major Professor
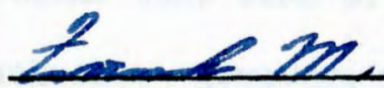

Head of Department

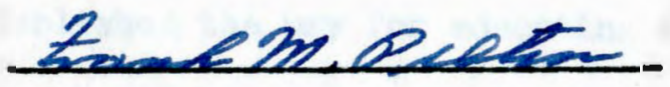

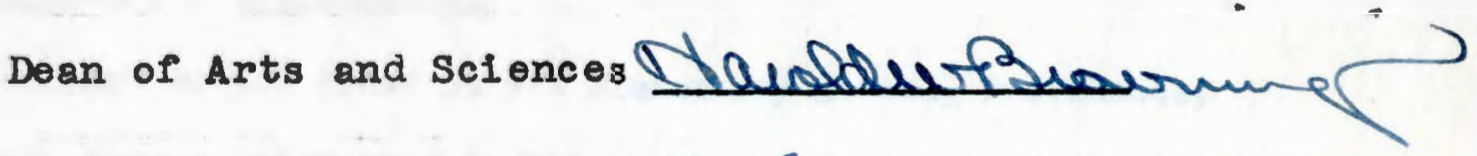
Director of Graduate studies 2

University of Rhode Island

1954 


\section{ABSTRACT}

Elementary schools have organized their curricula to insure the teaching of fundamental skills and subject matter, such as reading, writing, arithmetic, spelling, social studies, and art. Over the years, schools have assumed other responsibilities upon the insistance of the public which supports education. One of these added responsibilities has been education for citizenship.

Education for citizenship is a vague term and no one seems to know how this education is to be accomplished. For a number of years, there have been well conceived plans for attacking this problem in secondary schools with suggestions that some of these approaches might be adaptable for elementary schools. However, no objective evaluation of a program in operation has established the way for educating elementary children for citizenship.

Two teachers at the Broad Street Elementary School, Providence, Rhode Island, became interested in the problem and organized a project in citizenship for their fifth and sixth grades. The focus of this project was a study by the children of their Rhode Island heritage. This has been reported in another thesis. As the children worked, their activities were organized, directed, and supervised in such a manner that basic skills and concepts underlying good citizenship were developed and emphasized. This thesis gives a descriptive account of these activities. All evaluation of the project is personal, based upon observation and subjective appraisal of the behavior of the children involved in the project.

In developing the project, much attention was given to class organization, to individual and group work, to assuming personal 
responsibility, and to working together cooperatively. Community participation was a large factor in the success of the project. These are described in detail so that other teachers might find helpful suggestions for carrying out similar projects.

While having no objective data showing the effectiveness of this project for citizenship training, the writer concludes that in the light of her experience and subjective evaluation it was effective. Citizenship education comes not from subject matter but from group experiences, such as are herein described. 
TABLE OF CONTENTS

Chapter

I. Introduction ............... 2 The Problem. . . . . . . . . . . . 2 Reason for the study - • $\because$. . . . . 3 II. Building Cltizenship . . . . . . . . 6 Citizenship through Classroom Organization . . 6 Citizenship through Classroor Procedure. . . 6 Cltizenshlp through School-Community Influences . . . . . . . . . . 20 Citizenship through Communication. . . . 34 III. Conclusions . . . . . . . . . 49 IV. Recommendations. . . . . . . . . 52

v. Acknowlodgments. . . . . . . . 54 VI. Appendix . . . . . . . . . . . 55 VII. Bibliography .............. 62 


\section{INTRODUCTI ON}

The problem.--The problem for this thesis

deals with civic education for elementary school children, particularly those in grades five and six. It presents methods and activities carried on in conjunction with the teaching of'basic skills. In every classroom there is a definite place for the basic skills which must bo taught. Equally important is teaching chlldren to think.

Thinking is not possiblo wi thout a grasp of the basic skills. It requires knowledge. The individual who has a grasp of knowledge and is oquippod with the basic skills will do a far botter job of clear, creative thinking than one who is less wellequipped. Good, clear thinking also requires that the thinker bo in good physical, mental and emotional condition. Thinking is necessary in the areas of family living, work experiences, and citizenship. I

In grades five and six, Broad streot Elementary School, Providence, a special project in civic oducation was undertaken. Part of this project was the preparation and collection of materials, samples

\section{IEducation for Citizenship. Metropolitan}

School study council, No. 9. New York. 1949, p. V1. 
of industrial products, and other items showing the histery and development of Rhode Island. As "The Exchange Kit" this has boen discussed in another thesis. 1

As this profect was carried through a one year period, attention was given to various classroom procedures and instructional prógrams that would develop skills, understandings, and attitudes essential for good citizenship. This thesis relates those experiences of the children which were helpful in civic education. The content of the thesis results from the personal accounting of what took place and from personal evaluation based upon observation of the pupil's beharior.

\section{Reasens for the study.--}

The teachers of America are sharply conscious of the dangers that threaten democracj. They know that our free way of life must be protected against attacks from without and weaknesses from within. They are all fully aware that the schools must take a major part in this most urgent of all civic tasks! 2

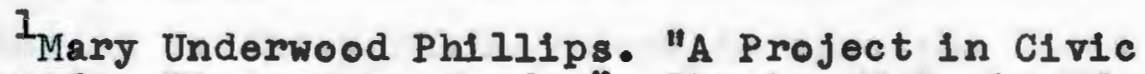
Education for Elementary Grades" Thesis, M.S. In Ed. University of R.I., 1954. Foundation. New $\frac{\text { Metter }}{\text { York. }} \frac{\text { Citizen }}{\text { p. } 3 .}$ 
This poses the problem of civic education which has been the conscious concern of junior and senior high schools for many years. With the realization of the importance for acquiring proper skils and attitudes in childhood, the formative period of life, elementary schools ape giving increasing attention to ways and means of developing good civic behavior and responsibility. How should it be done? There is no agreement among educators. The purpose of this study was to explore an approach to the problem in a given school situation. The project in civic education was carried on in a democratic climate, as far as the teacher was able. By this is meant that children leamed that democracy means froedom insofar as it does not interfere with the rights and freedoms of other members of the group. They reallzed that rules and regulations were necessary and thet once mede they hed to be obeyed.

Children had conferences and discussions with the teacher as to the part they were to have in cerrying out the units of work. From these conferences 
the children learned the following: the rights of an individual to disagree with another; the way to disagree without disparaging the other's point of Vlew; the art of listening while another spoke; and to accept criticisms and suggestions.

During the first conference children were very critical of each other if their, ideas didn't coincide. They interrupted the speaker when they did not agree. They insisted that the other child was wrong if his suggestions were different. As the school jear progressed, the children began more and more to respect the rights of the other individuals and to realize the courtesies required among people.

To learn these attitudes toward each other, techniques for sharing experiences and information, and ways of responding to group activity was the intent of the project. Within this concept of democratic behavior the activities of the pupils were organized. 


\section{BUI LIING CI TI ZENSHI P}

Citlzenship through classroom organization.-In order to help improve citizenship the classes of grades five and six were organized into groups. This was done so the teacher would have on opportunity to better acquaint herself with each individual pupil and his neods. To do this the teacher made a thorough study of the background of each member of the class including his chronological age, his intelligence quotient, results of achievement tests, and information from previous teachers. From this information the roading and aritkmetlc groups were formed. As the teacher worked with these groups, motivation which best fitted the group was used.

In reading and arithmetic homogeneous grouping was found to be better suited for developing skils and acquiring information. It was found by having heterogeneous grouping in these subjects, the slower learners were likely to withdraw from taking part in the activities.

In arf thmetic the children who had the ability to proceed at a faster rate were hindered by the 
slower children. Children with ablifty, waiting for slower children, might develop the bad habit of idleness. The slower children were not discouraged in a grouping of like abilities because it gave them a chance to recite and not have to sit, time after time, while the brighter ones came forward with the answer. These children felt competent, worked.hard to keep up with the other members of their group, and had the sense of satisfaction of being leaders in their own little group. Bad habits of indifference, defeatism, and lack of inltiative were lessened.

In reading a more elastic program was possible when reading groups were arranged according to ability. Strangely enough, it was not always the children who were best in arithmetic that were also best in reading. Many times the groups were quite different.

In all other subjects children of varylng ablities worked together. In social studies, sociometric grouping was used throughout. It gave the children the opportunity to experience all the differences that came from the various social, 
religious, economic, and racial groups represented while working with children of their choice. The advantages observed for this type of grouping include: it brought out the shy child; it encouraged every child to participate; it demended cooperation by all; it placed responsibility op efich member; it trained aggressive children to respect rights of others; and it gave all children leadership experience.

From experiences in the group activities, children learned the following:

1. to work with children of varying abilities, and of different racial, religlous, and social background.

2. to share their information.

3. to work cooperatively.

4. to accept differences in actions and oplnions.

5. to understand the rights and privileges of others.

6. to accept responsibilities.

These skills are essential to good civic behavior.

Citizenship through classroom procedure.--

Living today means belonging to a world community. It requires citizens with civic 
literacy. One must have not only the ability to read, write, and do arithmetic, but also the ablilty to think, discuss, and act on citizenship problems.1

Children should have a broader view of real life than is found in the text books. This connection between real life problems and what is found in the textbools can be made through properly adapted classroom procedures.

Every child likes to think he is somebody. He may not be outstanding in the classroom, but put him on a committer and he will soon take active part. He has been given a responsibility and is happy in carrying it out to the best of his ability. A valuable comittee in fifth grade was the current events or news comittee. News items of interest to the class were brought in by every member of the class and the members of the committee were held responsible for sorting them, arranging them, and mounting them. They took pride in arranging the articles according to type, such as sports, school articles, starting adventures, and world news. The committee aroused the interest of the class by having

$1_{\text {Teaching Current Events. (American Education }}$ Press, Columbus, 1947 ) p. 
a catchy phrase or a question at the top of an article. This conmlttee worked together anytime during the day when class assigments had been completed. During the opening exercises of each class day a short review was given on the topics and it was suggested that the members of the class take, time during the day to read these items. Puplis followed closely the recent contest on selecting the state bird because of their study of Rhode Island. Much interest was shown in ony article that had to do with this state. Questions and discussions always followed.

Some of the activities which resulted from the nows committee were:

1. studying the map for information about IndoChina.

2. comparing Indo-Chins with Korea.

3. listing all suggestions for license plate titie.

4. discussing purposes of meetings of heads of state.

5. listing qualities necessary for a secretary of state.

6. recognizing that history is being made every day.

7. studying the map for Israel. 
These are only a few of the many activities which resulted from the work of the news cormittee. It really served a dual purpose. It brought out good participation practices for the members on the committee. It also aroused interest in news items. This should give pupils an awarenegs for information in order to particlpate in civic affairs. Another important committee seemed to be for housekeeping. The class discussed the meaning and the items included under housekeoping, and they became more consclous of papers on the stalrs, in the schoolyard, or in the classroom. The teacher noticed that desks and chairs that were of ten set at all angles were being kept in line. When books were collected they were replaced in good order and so, too, was the inside of the children's desks. Materials used in activity or group work were collected and put away. At first, many children would just leave things when thoy had finishod with thom, but working in this cormittee taught the value of orderliness.

Another committee which gave children 
a certain amount of responsibility was the committeo on opening exercises. This group planned the exercises for each day. A patriotlc song was chosen, and a poem or a recitation was planned. A sllent prayer and a salute to the flag were used every day. A talk on news 1 tems was sometimes planned. It required planning, working with others, a sensé of rosponsibility, and a sense of pride in being successful. The library committee proved very popular. The classroom librariens were responsible for getting the books from the library and returning them when due. Pupils had to seo that the books were kept in good order in the bookcase and on the library table. When they took the books from the library they made a card file so that they know just what books they had. If the members of the class did not know how to make a card file, the teacher discussed it with them, and thon, at the conventence of the school librarian, took them to the library where it was explained in detail.

A group of children particularly interested In science asked if they might bring in their col- 
lections. Some of the things brought in were:

1. a collection of mounted butterflies.

2. a collection of shells.

3. book of mounted bird pictures.

4. a book of unusual animal pictures.

5. a collection of different kings of stone.

6. some stuffed animals.

Children were very willing to explain where and how they assembled the articles in the collection. They also wanted the other children to share in looking at them, hoaring about them, and in looking up information concerming them.

Committee work was very necessary in the activity work. Since the pupils seemed to get so much from the study of thoir heritage by loarning about Rhode Island and Rhode Islanders, they thought they would like to continue studying about people who helped the nation other than Rhode Islanders. They decided to study contributions to our culture made by people from forelgn countries. When the class decided it would like to study this, a discussion of aims and objectives took place. Ob- 
joctives were limited to the following:

1. to learn the true meaning of brotherhood.

2. to appreciate how people from every nation have enrlched our land.

3. to recognize the importance of our freedoms.

4. to accept willingly our duties and responsibilities.

Many ways of groupling for this activity were considered, and flnally the pupils decided they would like to form their committees according to areas. They formed the following committers: education, industrial research, science, art, music, fournallam, agriculture, transportation, and literature. Each child chose the committee he felt he would like to be on. In one or two instances, where too many were on a committeo some one would make a second choice. Since then, the comnittees collected books which would help them in their own depertments. They also decided to make a mural of scenes representing outstanding events in this country's advancement. In the center of this mural they thought a picture of the statue of Liberty would be appropriete. As new words appeared, the children listed and explained 
them to other members of the class. To form a bibliography each group kept a list of the books which were used. The pupils planned to make a map of the United States showing where certain nationalities settled, what typo of work they did, and why they chose that particular place to settle, and what effect these settlements had on the country. The children worked as a class when reporting on their books, giving summaries, and when reporting progress on what they had done. At all other times, work was done in groups or singly.

It was important to provide much resource material for all groups. The library table contained plenty of books, readable for the slow readers as well as the good readers. Magazines, art materials, and the like were avallable. (For books in the classroom, see appendix, page 56.)

From this committee work and group work these children were observed forming the following habits:

1. Keoping busy through worthwhile reading.

2. Accopting the responsibility of completing as sl gned tasks. 
3. Working without disturbing other members of the class.

4. Putting materials away and cleaning up whenever necessary.

5. Working with each other and sharing ideas and materials.

At all levels of leaming, children must experience problem solving. This can nót be done by memorizing passages from books. By having discussion groups chlldren must think. Research must be done, discussion carried on cooperatively, and sometimes conclusions drawn. Discussion provides for participation of all members of the class. "The discussion method assumes a problem one in which there is a difference of opinion. The general characteristics of discussion are:

1. A cooperative effort to arrive at the facts or conclusions about a subject.

2. Contributions come from many individuals, as contrasted with the lecture or debate.

3. Discussion starts only after careful and open-minded search for facts. The 1 gnorant particlpant destroys the value and fun of the discussion.

4. Participants share their facts and their conclusions and permit both facts and conclusions to be subjected to critical analysis. 
5. Participants are courteous and sportsmanlike in their attitude toward others." I

There are many forms of discussion. Some of these were used by the fifth grade children in the Broad Street School. These included panel discussions, press interviews, and club meetings. The panel discussion was tried and met with enthusiasm from the group. A chairman was chosen, and two or three others participated. When the research had been done the members of the group sat at table racing the class and each member made a brief statement giving his point of viow. The rest of the class foined in after the discussion had boen carried on for a whilo by the panel members. One interesting panel discussion carried on in this flfth grade classroom was on the topic, "Should Children Have Homework?" One child represented a parent, enother a teacher, and the third, a child. It was very onlightening. The children liked these discussions and were wllling to work hard in preparation for them. Toplcs suggested by the children

\footnotetext{
$1_{\text {Teaching Current Events. (American Education }}$ Press, Columbus, ohto. 1947) p. 10.
} 
included:

1. Why We Should Help the Community Chest.

2. Value of School Banking.

3. Why Should We Help the Red Cross?

4. What Can We Do for Clean-up Week?

5. How to Get Along with People. "

6. Do Comics Influence Children?

7. Why We Should Learn about Civilian Defense.

8. Fire Prevention.

occasionally a group plannod a press interviow. Three or four children represented the press. A "public figure" was questioned. There was a moderator who controlled the questioning. The members of the class were the observers. Questions pertaining to actions of boys around the school were asked.

Club meetings were another form of discussion. A serious discussion on the qualities to look for when voting for a class officer took place before voting for him. After the discussion and when the preliminary work was done, pupils were allowed to vote by secret ballot. It was very rare 
that an outstanding pupil was not chosen as leader. As near as possible these club meetings followed simple, parliamentary rules. In this fifth grado class club metings were held every second woek. They were usually pretty lively and interesting topics were brought up for discussion., When something pertaining to the school, such as passing, or school yard activities, was brought up and motions made, a conmittee was appointed to make an appointment for a conference with the principal. Interest in school rules and school responsibilitlos was greatly aroused by this technique.

Schools should be discussion consclous... because in a democracy, discussion is a form of action on the part of citizens in maing thelr government offective - because in a democracy, if youth discusses contemporary affairs now, intelligent discussion will inereasingly become the habit of the Nation because in a democracy, citizens both old and young, must banish ignorance of contemporary affairs within themselves and anong others - because youth should lesm how to share ideas in discussion, for dolng this fosters their growth as oftizens.

Because when ideas, based on facts about contemporary affairs become more widely shared through discussion, civic life becomes more dynantc - because the way of discussion is the democratic way. 1

$1_{\text {Teaching Current Events. (The American }}$

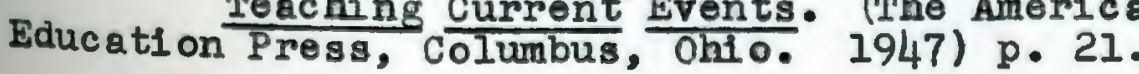


Through observation it was noted that the techniques of discussion helped children to:

1. prepare facts accurately

2. organize these facts

3. Think clearly

4. state facts concisely

5. work with members of a group cooperatively

6. listen to others attentively

7. act courteously

8. use correct English

Good civic habits were formed by these experiences. The teacher noted that the children became interested in news 1 tems, in current happenings, and in geographical locations of current interest. The teacher also noted that the children were asking Intelligent questions on current news, thinking critically on topics, expressing themselves with clarity, and accepting responsibilities for getting information.

\section{Citizenship through school-community in-} Pluences.--The school utilized the resources of the comunity in three ways. First, the children were 
taken from the school bullding to study the various activities and materials of the community at first hend. Second, people were brought to the school to help children interpret their environment. Third, concrete materials from the comaunity were used in the school. The best use of community materials and experiences demands careful preparation on the part of the teacher, and understanding on the part of the supervisor and administration. Teachers, as well as pupils, may need to make simple trips that noed identification. The teacher must be familiar with all aspects of the trip.

These out-of-school activities sponsored by the school were justifled only when the total leaming values achieved by them were generally superior to those possible through other instructional procedures.

It must be admitted that there are units in the curriculum for which the use of community materials is not only difficult to arrange but is artificial. If not well managed, such efforts may become a nuisance to everyone concerned. Probably 
a great deal of very valuable school time is now wasted by too many excursions that are poorly planned.

Fleld trips.--Groups frequently reach a point in their classroom work when actual experience is necessary if learning is to bo effectire. The excursion meets the need. Through study trips in the community and region, the danger of losing touch with realit and mere verbalisms instead of meanings can, to large degree, be checked.1).

The success of an excursion depends upon the offlefency of the leader and the ground to be covered should be famillar to him. The children should record certain data and upon returning to the classroom should have a follow-up of some typo.

The fleld trip offers a wonderful opportunity in developing social graces and character training. It offords an opportunity to write thank-you letters and a chance to show good manners through proper behavior.

Because it is belleved that the field trip is worthwhile in that it provides a personal experience, dovelops a sense of reality, creates interest, arouses curlosity, and helps to dovelop cooperation, the children of Broad street school took many field trips.

1

Ut1lizing the Local Enviroment. Margaret Koopman, Dept. of Superintena ence, IIth Yoarbook, The Social Studies Curriculum, Washington, D.C., p. 30 . 
In connection with their science lessons, the children in the flfth and sixth grades took a number of trips to Roger Williams Park Museum. One Visit was to the planetarium. The curator gave a lecture and demonstration. This visit was a revelation to the scientiflc-minded child. It stimylated the others to think, to wonder, and perhaps to develop a new interest. In everyone there was a feeling of pride because Providence was so fortunate to possess a planetarium. The majority of children attending felt that it belonged to them for many of them had contributed toward the plenetarium drive. Some classrooms had recelved "deeds" to the Milky Way or other places in the sky, depending upon the size of the contribution. When the groups returned they immediately wanted to look up more information on the stars and planets.

Another trip was taken to the park in connection with the study of conservation. The director of the visual oducation department took the class on a tour of the grounds and explained various land $L$ formations and the different kinds of trees. 
Broad Street School is fortunate in its location in that its neighboring areas provido so many educational advantages. The Roger Williams Park Museum has daily classes held after school and on Saturdays. Here, many of the children study astronomy, minerelogy, and general nature study, In this way, the children's eyes are opened for the first time, perhaps, to new fields. Information was often correlated with school subjects. Careers may even be started along scientific lines. Initiative was developed in those students who folned classes voluntarily. Training in research work was begun. Promptness and perfect attendence were encouraged. The sixth grade took a bus trip to the museum for an illustrated nature lecture followed by a tour of the museum. Observing the animals in the museum with the proper background created a desire among many of the children to find out more about them. Following this visit reports were given on what they found most interesting. Some of the children wrote stories and poems about the animals and others drew sketches of them. Discussions on the value of this sort of trip led to the need for 
care in observing all the rules connected with the park and the park museum.

A branch of the Providence Public Librery is located in the Broad Street School. The pupils had an opportunity to go there during the day for research, special reading, and instruction on how, to use the library. This consisted of the proper cere of books, finding information in reference books, the value of the card catalogue, the location of different types of books, and, of course, library etiquette. When the children wanted information on Rhode Island horoes, they were allowed to go to the library and 10ok up information in reference books. In preparation for their reports and discussions the children were free to go to the llbrary for needed research.

The children of Broad Street School were invited to hear the Philharnonic orchestra at the Veteran's Auditorium. The response from the children was enthusiastic. The majority of them sat enthralled. No doubt, many of them were hearing good music for the first time. For those who study music a familiar tune was a dellght. A trip of this kind provided an Ideal opportunity to stress what is or isn't done at 
concerts of this kind. The preparation and followup of this trip is explained in a later chapter.

Resource visitors.-- The term, 'resource visitorsi is applied to people, who cen demonstrate accomplishments or particular abilities which are of interest and value to school pupils, and who are also able and wiling to display, discuss or otherwise present their attainments before a student group. Resource visitors are generally utilized for serious educational purposes rather than for mere entertainment. 1

There are many people in the neighborhood with fine backgrounds who could enrich a school program by providing some worthwhile information. Therefore, It is woll to keep a human"file of available peoplo in the office of the school. Perhaps someone has traveled a great deal who could enliven a geography losson. A good reader or story toller could inspire the pupils to be good readers. An interesting hobby, a travel movie, a talk by a fireman, policoman, etc., are all of value.

The resource visitor not only provides real experiences but he can be an inspiration to his young listeners. Respect is developed between the adult and the child. The exporience is two-fold.

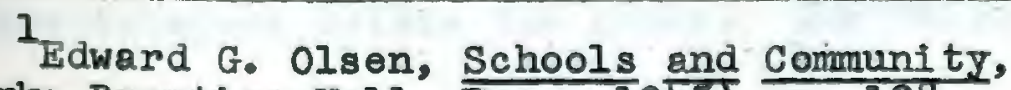
(Now York: Prentice-Hell, Inc.. 1945), p. 128. 
The visitor gets a better understanding of what the school is trying to accomplish. The child has a chance to develop the social graces.

As in the field trip, if a talk by a resource Isitor is to be successful, it must be well plenned. The speaker must first be contacted to see if he is arailable. If so, a definite date and time may be set. Transportation can be provided, if necessary. The speaker should be informed as to just what to expect as to the age of the chlldren, material that will be on hand, the size of the room in which he is to speak, the length of his talk, etc.

The children's interest should be aroused as they awalt the day of the coming speaker. Posters on display w1ll help do this. Good manners should bo emphasized, and the children should understand that their attitude not only reflects on the school's reputation but shows their home training also.

Following the visit there should be a discussion and record filed for future reference. There are limtations, too, in this sort of activity. Some people may possess valuable information but refuse to speak before the group. The unfamiliar 
stories about how she made her collaction. It was a very successful talk and was followed by class discussions. Letters of thenks were sent to her by the children.

Another parent was invited to talk about hor ceremics. She had some finished pieces and also the clay and mold to start a new piece. She went through all the teps to the baking. The children were sascinated. Many interesting questions were asked by the children.

In connection with book weok, the princlpal invited a nelghbor who had written chlldren's books to speak to the children. He read from some of his books and also gave a summary of others. Many questions were asked him in regards to writing. Some wanted to know how he started. Others wanted to know how long it took and how many ho had writton. All had interesting reports to give on the talk. The librarian also talked in connection with book week. She had many book jackets on display and talked on the various types of books interesting to children. 
The curator of the museum was another speaker and, as always, provided an inspiring talk on nature. She had a few of her own books that had been published on display. She also talked on how she came to write books.

Visits like these at the Brosd Street School holped to develop a better relationship between the child and the adult. It brought them closer together and In a different setting. Such understandings brought about the desire to leam more and to help in every way possible.

Children were stimulated by the visits to borrow more books from the library. Books were selected earefully and for the proper age level. More children joined classes at the museum. They became conscious of boautlful Roger Williams Park and the advantages it offered. To help preserve these many privileges in the park became the duty of each child. From each child it was also carried into the home to younger brothers and sisters.

Personal interviews give veluable resource material. These usually are held in a person's 
place of business or residence. The procedure is Informal and is usually in the form of the question and answer method instead of a prepared talk. The child may hold interviews with helpfil people who are not actually connected with school procedures. The teaching program can be enrighed by encouraging students to interviow local residents. In overy community there are citizens who possess worthwhilo experiences, interests, and knowledge. The interviow gives young people an opportunity to meet and talk with mature people on some problems of common concern. By so dolng, they themselves have advanced toward maturity.

As in the fleld trip, before the actual interview takes place there should be definite proparation. First, there should be a group discussion concerning the purpose of the interview. once this has been declded upon, the group can select the person or persons to Interview who can best serve the purpose. A "human file" can determine this. It is nocessary to study the qualitios and oxperiences of this selected person for the student should plan to ask intelligent questions as well as to listen. 
A decision should be reached as to what questions should be asked, what should be recorded, and most of all, to remember not to exhaust the interviewer. Following all this comes the act of contacting the gelected person to acquaint him with the objective. This should be done by the teacher or a mature student. It may be accomplished by a personal interview. Once the group learns the chosen interviewer is willing to cooperate, more planning needs to be done. If necessary, travel arrangements should be made. Promptness, good behavior, and little acts of courtesy should be stressed. Upon returning to the classroom discussions should be held, final reports written out and filed for future reference. Children at Broad Street School had interesting interviews. A group of boys took it upon themselves to Visit the Governor of Rhode Island. They thought he could inform them in regard to a certain project they were undertaking. Childilke, they found themselves outside the Governor's office w thout an appointment. Through his kindness and graclousness, however, they were ushered in and treated most royally. They recelved not only the 
information they went after but pamphlets, a state seal, and the Governor's signature besides. During the conversation the boys learned the Governor's date of birth. True to form, when the day came, the boys were back with gifts for their new friend. Through such an unrehearsed visit the boys gained much. They learned that great people are humble, that people in high office are as a rule, sincere, kind, thoughtful, and never "too busy"; that it is fun to cooperate and to share. When the sixth grade class was studying communication in their social studies lesson, an Interview with a telephone employee was arranged. This interview was held in the telephone building. It was held to plan for the class to go on a tour of the bullafng. The kindly attitude of the gentloman made the children eager to ask intelligent questions. Once again, a good child-adult relationahlp was established.

The school child of today is no longer confinod to four walls. The conmunity itself has a place in the school program for it has much to offer in the onrichment of a child's leaming experiences. 
This may be in the form of fleld trips, resource visitors, or interviews. The personal contact with people and places has a definite effect on children. Through these experiences in the community, pupils in this project learned to write courteous letters, to behave properly in a publi'c bullding, to use proper form of address, to appreciate civic or business leaders, to foel a part of the community, and to take pride in the community and its leaders.

Citizenship through communication.--It is desirable to have for educational use, fl lms produced for the purpose which deal inspiringly with the problems of life and the world; also films designed to instill in students those elusive elements, which form character, c1t1zenship, and goodness.I

Interest and eppreciation of good, worthwhile movies were stressed in the classroom. This was done by very indirect methods. Children were exposed to good reading. Interest in the right types of literature lod to interest in the right lind of movies. Many of those storles were dramatized

$1_{\text {Elizabeth Laine, Motion Plctures and Radio }}$ (Now York and London: McGraw-HIII Book Co., Inc. 1938) p. 22 . 
and when the same type was shown on the screen the chlldren wanted to see them.

After reading the King Arthur stories, many of the children saw "Knights of the Round Table." The next day some of them gave a summary of the picture. A discussion was held on what the children hed learned from that picture. This can be done with many good pictures. The children in this fifth grado classroom read the book, "Heldi." It was going to be shown in a theater in a week or two. After reading It and talking about it, many wanted to seo 1 t. Simlar preparation can be made for many worthwhilo motion pictures. It might be a fantasy such as "Snow White" or "Allce in Wonderland." These books can be read by members of the class or as is frequently done in this fifth grade classroom the story is read by the teacher. They can learn what a pantasy is and know what to expect when they are seelng one.

A panel discussion on worthwhile moving pictures created much thinking by the class. The children realized the worth of good movies and the dangers attachod to too rrequent attendance. Toples relating to this medium of entertainment and in- 
formation were:

1. How often should we attend movies?

2. Should we know what picture is being shown before attending?

3. What type movies are good for children?

4. When are movies recreational?

When possible, after school povies were held at a minimum cost followed the next day by a discussion. By belng exposed to good movies, the urgo to attend "just anything" was minimized.

Much has been done in the classroom with oducational movies. The Providence School Department has an excelient solection of moving pictures which can be and is used in the school audtorium. Many of these fit in very woll with the social studies curriculum.

Broad Street School is fortunate to own two machines. The one used in the auditorium is a Bell and Howell which is a $16 \mathrm{~mm}$. movie projector. Boys were taught to mun this machine under a teacher's supervision. Only boys who could be trusted were allowed to partake in this activity. This knowlodge, no doubt, played a part in developing better civic pattems in the minds of these youngsters, for the 
majority were most eager to learn this sill.

The other machine is a view-lex which is a combination of a slide and filmstrip projector. Flimstrips on science, arithmetic, and pemmanship were only a few of a large selection owned by the school.

Two boys were chosen to take care of this machine. It was their obligation to plan a satisfactory schodule for its use. After the showing, the oquipment had to bo carefully put away. These boys were held responsible for their classroom assi gnments and could not noglect any of their work in order to run this machine. They were taught the proper care of valuable equipment which belonged to someone else.

Through the use of educational films in the school, children lesrned:

1. science, social studies, and other school subjects through the physical senses, nemoly those of hearing and sight.

2. the art of careful listening and watching.

3. to roport on the films shown.

When the children were ready to study Daniel Boone, a discussion was carrfed on. Then the class 
was taken to the auditorium to see the movie, "Daniel Boono." After watching the picture, the children asked many questions and were anxious to read about the adventures of Boone. It was an excellent means of motivation. The same procedure was followed with meny other pictures, some of which ware. The Star Spangled Banner," "Lincoln in the white House," "Lincoln's Gettysburg Address," "Land of Liberty" (4 parts - 5b, 5a, 6b, 6a). Before each movie, a preparatory discussion took place. Following the movie, there was further discussion and all were anxious to study and learn more about these topics. Movies on Roger Williams and Rhode Island were shown in connection with the preparation of the IExchange Kit', another part of this project on civic education. The filmstrips were used in the classroom whenever the noed arose. During a science lesson the word, conservation, came up. The class was shown fllmstrips on conservation, making it much more meaningful to them. During the activity in connection with the 'Exchenge Kit', children were making book covers and arrangements with paper, so the filmstrips on paper 
sculpture were shown. After seeing them, the children were ready to try things on their own. Many of the other filmstrips were used in the same way. As the need arose, the picture was shown.

Redio and television.--Next to movies, radio and television are a vital force in forming the attitudes of young poople. A popular comedian, a musical artist, an educational forum, all have their followers among chtldren. Many hours are spent by most children listening to the radio and watching televiaion. More often, it is television. The school should try to creato right thinking on the part of youngsters as to what is valuable and what is best to avold.

At the prosent time, in the secondary schools, television sets are being installed. By having these, meny worthwhile progrems can bo hoard and seen. There ahould always be preparation and motivation for these programs and a follow-up so the value of the program won't be lost.

Hore is where our short talks can do much in having some influence on radio and televigion 
Iistening. The teacher should bo alert to programs and suggest to the children that they listen or watch so as to be able to give a brief report on the program to the class. If this is made a regular part of the day's work, chlldren will make an effort to listen so something worthwhilo can be repeated to the class. Soon they will bocome conscious of the worthwhile programs.

A number of schools today have radios. Opportunities for children to take part on radio programs should bo encouraged. Such experiences may open the way to a radio career. In most instances, it will, in all probability be a memorable event in each performer's ilfo.

The use of this medium, however, is limited to a certain number of pupils. This drawback can be alleviated somewhat by making use of the public address system and using phonograph records for background. Children in the Broad Street School have done this very thing. As there are loud speakers in each room, it is easy to create a radio illusion. Programs have been given on current events, plays, book reports, and special holldays. 
Programs of this type were very valuable for they taught the children to enunciate clearly, to be well poised, to be accurate, to be prompt, to accept pesponsibility, to do research, and to plen worthwhile progrems.

children, as a rule, wanted to participate in such programs. Therefore, there was a great deal of competition, and as a result more and more children worked to acquire the qualifications so that they, too, might be chosen to take part.

Television is recognized as an important medium for communication. It brings events of the day to the student even as they are happening. The values gained from programs of a scientific, professional, industrial, historical, or musical nature are Important contributions.

Children of Broad Street School have participated on television programs. The values are similar to radio and the child reallzes he must leam to be polsed, to speak clearly, to be pleasant, to be prepared, to be punctual, and to be rellable. Allowing children to discuss what they had 
seen on television gave a fine opportunity for directing them to the types of programs most valuable. Then, too, many of their own chlldhood fears were overcome. The children discussed a television progrem which portrayed the Imaginary horrors of a child and how she came to realize that her fegrs were unfounded. They were then asked to writ te a story entitled, "My Most Ridiculous Fear." Some of the stories were very good, and even the children who hedn't observed the program were able to write freely about their fears. This, the teacher felt, was a very good way of lessening these very fears. A similar activity was tried after a discussion of a program where the father in the story had a joke played on him and what good sport he was about it. The children then wrote on, "The Funniest Joke Ever Played on Mon.

When the children told about listening to, "Moet the Pross", for instance, they were asked what they noticed about the group. The answers were:

1. They were oourteous.

2. They had good speech habits.

3. They used clarity of expression. 
4. They had well thought out questions.

5. They listened carefully when anyone was speaking.

Every weokday morning there is a short radio program called, "Streets of Our City." Many of the children were interested in listenling to this because of their study of Rhode Island.

When the children were planning a "Meet the Press" program in school they watched the television program of the same name. The next day they discussed what they observed and how they could use these observations on their program. They also listened on the radio to the Chicago Round Table and America's Forum on the Air to get ideas for thelr di scussions.

Other media of communication which influence behavior are books, newspapers, and magazines.

Reading preferences differ widely according to the mental age, chronological age, home environment, roading achievement, the home influence, and avallability of materials.

Classroom experiences help develop the 
desire for reading and discrimination in what is read. The reading table or library corner in school is a big influence on reading habits. Once the children became interested in a certain type book, they were anxious to read more of the same type. For instance, it has been found that as the 'children, boys particularly, have read one of the Landmark Books, they were anxious to read more of them. In the classroom at the Broad Street School they had this opportunity of becoming acquainted with these books. In connection with this set of books, records based on the stories have been released. The Broad Street School has purchased these and some of them have been tried out in the classroom. The children instantly liked them. After listening to the recording there was a great rush for the books. The records tell the story in conversation form. There is a musical accompeniment throughout the record. After listening to the record it is possible for a group to dramatize the story. The records include:

1. Voyages of Christopher Columbus.

2. Landing of the Pilgrims.

3. The California Gold Rush. 
4. Riding the Pony Express.

5. Paul Revere and the Minute Men.

6. our Independence and the Constitution.

7. Building the First Transcontinental Railroad.

8. Wright Brothers - Powers of Americen Aviation.

9. Exploration of Pere Marquetto.

10. The Lewls and Clark Expedition.

11. The Monitor and the Merrimac.

12. Lee and Grant at Appomatax.

13. Stephen Foster Songs.

Interest aroused in the classroom concerning blographies was also transferred to outside reading. The Ilbrarian at the Broad Street School reported that many of the children asked for these books for home reading.

The news corner trained the chfldren on what to look for in a newspaper. The boys brought in clippings from the sports page and were very capablo or reporting on them. News items on current events stimulated much class discussion.

Newspapers were used in prepsing the IExchange KIt'. One of the children brought in a copy 
of a newspaper printed in 1936 and used it in the classroom. Children read 1 t and reported on articles and stories from 1t. They later used the information they had read in writing their stories on cultural Rhode Islend. Pictures were cut out from this paper and pasted in the scrap book. Current newspapers were also used in the activity. Some of the stories read in the paper and later reported were:

1. Story of a Rare Coin.

2. Quaker Meeting in Foster

3. The Only Battle of Rhode Island. Many magazines should be on hand in the classroom. The reading table included the following:

1. The Weokly Reader.

2. Reader's Digest Reading Skill Builder.

3. American Junior Red Cross.

4. Jack and Jill Books.

5. Story Parade.

6. American Girl.

7. American Boy.

8. Boy's Life.

9. Junior Natural History. 
Most of these books and magazines are written so as to arouse the interest of youngsters. The habit of reading this type of story was formed and so the majority of children called for thils same type later. All children in the flfth grade had library cards and were encouraged to use them. All types of stories were avalable and since the children had been giving and listening to reports on biographies, imaginary stories, history, mystery, animal, and every other type of story, they were familiar with all kinds of good reading.

Music plays a role in developing attitudes underlying good citizenship. Feelings of patriotism are certainly stimulated by appropriate music. Folk tunes help children understand the culture of people. In this project, music was used including "The Star Spangled Banner," "America," "America, the Beautiful," "Columbia, the Gem of the Ocean," "Battlo Cry of Freedom," "Young America Sings," "O Groat America," "Tenting Tonlght," "America for Me," and "Battle Hymn of the Republic." The story behind the lyrics was taken up in detail with each selection. 
In the case of "The star Spangled Banner", the movie was shown where Francis Scott Koy was seen on the ship as he recited the words. After the story behind these patriotic selections was heard, the children sometimes dramatized scenes from the story in the song. The words sacrifice, Ipve, honor, obey, trust, and defond were brought out in connection with these songs.

When the children sang the stephen Foster songs, an interest was aroused to learn more of the history of the South. Their appreciation of the simple wants of the Negroos was learned as they sang these southern tunes. The story of "bixie" and the friendiness and understanding of Lincoln when he requested that the song be sung at Gettysburg, were strongly felt. Around this same time, they were shown the movie and were deeply impressed.

Songs used in connection with the IExchenge Kit' were "For the Beauty of the Earth," "The Thanksgiving Song," and "Rhode Island Fair." 


\section{CONCLUSI ONS}

This project in civic education was undertaken to give children a better understanding of their civic duties and responsibilities while developing those skills and acquiring that information which characterizes the curriculum of a fifth and sixth grade. This thesis recounts, in some detail, the activities and experiences, as they took place, which were organized to educate children. Attempts at evaluation are those made by the classroom teacher as part of her teaching routine.

Citizenship is a long-renge problem and derinte results can only be found after a period of years. However, some instances of the results of this activity have become evident in the community, as observed by the writer and commented upon by parents and other adults in the community. Better manners have been observed in the park museum, in the library, in the locel movie house, at the school, and on the playground as well as in the homes. Children have been observed to take more interest in keoping the classroom clean and orderly. Acts of kindness have been noticed and commented upon. Students assumed and carried out responsibilities in completing school assignments, in doing home chores, in holping other children. These conclusions were drawn from observations 
made in the classroom and around the school building. The author also talked with parents and businessmen in the community. The parents commented on the interest taken by the children in the home. The people in the business places observed less annoyance by the children and more courtesy when in their establishments on business. Reports' reached the author on the obedience of many children in the local theater and their willingness to remain in their seats and be quiet. In the recreational groups it has boen reported that botter attitudes of sportsmanship have bocome evident. The librarian stated that more of these children were taifing out library books and seemed to know what they wanted. Sho also reported that they were very alert about getting the books back when due. The curator at the park museum felt more interest was stimulated among these children toward museum classes. When a classmate was out with an iliness that was to bo rather long, some childron suggested sending letters, gifts, and cards. Other children offered to go to his home and help him along on any work he was missing.

These are instances of good civic traits and 
oven though it is impossible to get any real tangible results the author feels an excellent start has been made in molding the citizenship habits of these children in the right direction. 


\section{RECOMMENDA TI ONS}

The problem of this thesis was based on the need for improvement in teaching citizenship. From experiences with this project, the following recommendations for teachers are suggested:

1. Have avallable not only such resources as books, magazines, visual aids' pamphlets, news items, but also community resources.

2. Carry on activities according to a democratic patterm, as club meetings, discussions, group working and planning, centers of interest patterned after real iffe situations.

3. Encourage creative work in the classroom as planning a science corner, a news corner; clean-up and safety campaigns, including the mading of posters, writing stories, mottoes and poetry.

4. Use functional methods in all teaching of manners, on the bus, in public places, in games and sports, on the playground, and in relations with all school companions.

5. Create interest in the study of biographies of outstanding citizens.

6. Teach the worth of cooperative living through group planning in social studies, learning to give and take, worling out classroom rules and regulations, sharing knowledge with other members of the group, learning to try to understand the other fellow's point of view, and helping younger or slower children. 
7. Foster the necessity of active responsibility by having them serve on committeos, prepare booklets on interesting placos to visit for field trips, form lost and found committees, carry on a library program, work for welfare as making articles for veteran's hospitals, filling Rod Cross boxes, making articles for chlldren's hospitals, operating visual aid equipment, and taking pride in school grounds.

8. Show example by participating in P.T.A. meetings and activities, performing civic duties, and keoping up on current events.

9. Inspire good and worthwhile use of leisure time.

10. Guide discussions on pertinent topics as Hallowe'en, fun, safety, firo provention, and health.

11. Encourage community-school cooperation, interviews, speakers, P.T.A., local history study, open house, and recreational activities.

12. Analyze the citizenship problems of your community and develop your program of olvic education in terms of them. 


\section{ACKNOWLEDGNENTS}

The writer is greatly indebted to Dr. Frank

M. Pelton and Dr. J. Edward Casey for help and advice in organizing and developing this thesis. 
APPENDI $X$

$$
1 \div
$$


Lists of Books for Fifth and Sixth Grade Children

I. Allabout Books

Andrews, Dr. Roy Chapman Gould, Jack

Lane, Ferdinand $C$. Pough, Fredertck H.

Tannohill, Joan Ray
All About Dinoseurs

All About Radio and Television

All About the Sea

All About Volcanos and Earthquakes

(AII About the Weather

II. Blographies

A. Group

Bailej, Cerolyn sherwin

Baldwin, James

Bolton, Mrs. Sarah

Brooks, Elbridge S.

Cather, Mrs. Katherlne

Cottler, Joseph

Cruse, Mrs. Amy

Fraser, Chelsea A.

Olcott, Francis J.

Parkman, Mary Rosetta

B. Indi vidual

Brockhousen, Anna

Darrow, Jane

Children of the

Handicrafts

Four Great Americans

Washington

Franklin

Wobster

Iincoln

Famous American Authors

Famous Men of Sclence

Lives of Girls Who

Became Frmous

Lives of Poor Boys

Who Became Famous

Hi atorlc Americans

Boyhood stories of

Framous Men

cirlhood Stories of

Famous Women

Heroes of Civili-

zation

Boys and cilrls who

Became Famous

Famous American

Fljers

Good Stories for Great Birthdays

Heroes of Service

Andrew Carmegie

Nathan Hale 
B. Individurl (Cont.)

Hallock, Grace Tabor Edward Jenner

Haw thorne, Hildegarde Oliver Wendell Holmes

Purdy, Mrs. Clairo Stephen Foster

Putnam, G.

Amelia Earhart

Richards, Mrs. Laura Jane Addams

Sullivan, A. M.

Helen Keller

III. Gateway Books

Moran, Eugene F.

Famous Harbors of the World

Nathon, Adelo G.

Steinman, D. B.

Talbert, Ansel

White, Edward E.

Famous Rallroad Stations of the World

Famous Bridges of the World

Famous Alrports of the World

Famous Subways, Tubes, and Tunnels of the World

IV. Landmark Books

Adams, Samuel H.

The Erie Canal

The Pony Express

Brown, John Mason

The Santa Fe Trail

Conaldine, Robert

Daniel Boone

Cousins, Margaret

The Panama Canal

Ben Franklin of old Philadelphia

Dougherty, James

Landing of the P1lgrims

Trappling and Traders of the Far West

Fisher, Dorothy

Our Independence and the Consti tution

Paul Revere and the Minute Mon

Forester, C. S.

The Barbary Pirates

Holbrook, Stewart

Hunt, Goorgo

Janeway, Ellzabeth

Jennings, John

Johnson, Will1 am

Kantor, Mackinlay

Wild Blll Hickok Tames the West

Story of the U.S. Marines

The V1ldings

Clipper Ship Days

Sam Houston, The Tallost Texan

Gettysburg

Kjolgara, Jim

Lee and Grant at Appomatox

Coming of the Mormons

Explorations of Pere Marquette 
Landmark Books (Cont.)

Lawson, Marie

Lawson, Ted and

Consi dine, $\mathrm{Bob}$

Mason, Van Wyck

Mayer, Jane

McNeer, May

Nathan, Adele

Newberger, Richard

Owen, Russell

Plnkerton, Robert

Pratt, Fletcher

Reynolds, Quentin

Sheen, Vincent

Shippen, Katherino

Sperry, Armstrong

Tallant, Robert

White, Ann Terry
Pocahontas and Captain John Sint th

Thirty Seconds over Tokyo Winter at Valley Forge Botsy Ross and the Flag California Gold Rush Building of the First Transcontinental Railroad

Lewis and Clark Expedition Conquest of North and South Poles

First Overland Mall

Monitor and Merrimac

Custer's Last Stand

The Wright Brothers

Thomas Jefferson, Father of Democracy

Mr. Bell Invents the Telephone

John Paul Jones, Fighting Sallor

Voyages of Christopher Columbus

Pirate Lafitte and the

Battle of New Orleans

The Louisiana Purchase

George Washington Carver

Prehistoric America

V. Real Life

A. Explorers and Early Settlors
Congdon, V.E.
Cottler, J.
Dosoto
Emerson, C.D.
Roger Williams
Leighton, $M$.
stuyvesant
Nolan, J.C.
John Smith
WeIr, R.C.
La sallo
Columbus

B. Leaders of the American Revolution
Cavanah, F.
Condon, V.E.
Cottlor, J.
Holberg, R.L.
Neilson, F.F.
Weir, R.C.

Washington

Father Serra

Jefferson

Abi gail Adams

Franklin

John Paul Jones 
C. Leaders in Western Expansion

$\begin{array}{ll}\text { Judson, C.I. } & \text { John Jacob Astor } \\ \text { Knoop, F.I. } & \text { Zebulon P1ke } \\ \text { Nolan, J.C. } & \text { Daniel Boone } \\ \text { Phillips, J.E. } & \text { Rufus Putnam }\end{array}$

D. Leaderg Since 1850

$\begin{array}{ll}\text { Blackstock, J. } & \text { Jane Addams } \\ \text { Bontemps } & \text { G. W. Carver } \\ \text { Cavanah, F. } & \text { Lincoln } \\ \text { Graham, W.W. } & \text { Thomas Edison } \\ \text { Solem, E.K. } & \text { Robert E. Leo }\end{array}$

VI. The Childhood of Famous Americans Series

Bebenreth, Charlotta

Bryant, Bernice

Burnett, Constanco

Burt, olive

- -

- -

Clark, Elocta

Guthridge, sue

Henry, Marguerito

Hif ggins, Helen

- -

- -

Howe, Jane

Long, Laura

- -

- -

Mason, Miriam

- - -

- -

- -

- -

Mitchell, Minnio Monsell, Helen

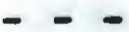

$-\infty$

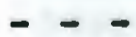

Merlwether Lewis

Dan Morgen

Lucretia Mott

Luther Burbank

John Wanamaker

Young Jed Smith

Robert Peary

Tom Edison

Robert Fulton

Alec Hamilton

Stephen Foster

Juliette Low

Amelia Earhart

Oliver Hazard Porry

David Farragut

George Deway

Mark Twain

Young Audubon

W111 am Penn

Mary Hapes Dodge

Dan Beard

Hoosier Boy

Boy of old Virginia, Robert E. Lee

Thomas Jefferson, A Boy

in Colonial Days

Young Stonewall, Tom Jackson

Dolly Madison, Quaker Girl 
VI. Childhood of Famous Americans Serles (Cont.) Monsell, Helen Henry Clay, Mill Boy of the Slashes

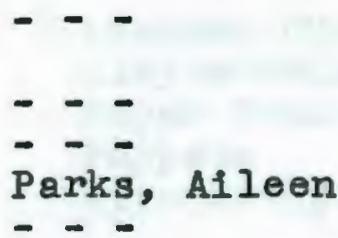

Parks, Ed Peckham, Howard

Seymour, Flora

- -

Smith, Bradford
John Marshall, Boy of Young America

Woodrow Wilson, Boy President Susan Anthony, Girl Who Dared Davy Croclrett, Young Riflemen Bedford Forrest, Boy on Horseback

Teddy Rooseyelt, All-Round Boy William H. Harrison, Young TH ppecanoe

Bird Girl, Sacagawea Pocahontas, Brave Girl

William Bradford, Pilgrim Boy Dan Webster, Union Boy

VII. Junior Literary Guild

Aldis, Dorothy

Ajars, James

Allen, Allyn

Brink, Carol

Carmer, Carl

Carter, Page

Cholmers, Audroy

Carpenter, Frances

Devis, Lavinia

- -

Eames, Genevieve Erlckson, Phoobe Hogeboom, Amy

Johansen, Margaret Jones, Ruth Liers, Bmil McMeokin, I sabel o'Neil, Hester Paradis, Marjorie Richardson, Myra Robinson, Tom Sterling, Dorothy Wallace, May Warner, Priscilla Warren, Bll1y Whit te, Anne Wilson, Leon
Lucky Year

Basketball Comes to Lonesome Point

Lone Star Tomboy

Family Grandstand

A Flag for the Fort

The Ghost Hollow Mystery

Hilg Smoke

Wonder Tales of Horses and Heroes

Sand's Spur's

Secret of Donkey Island

The Good Luck Colt

Black Penny

Christopher Columbus and his Brothers

The Wooden Locket

Bay of the Pyranlds

The Otter's Story

Ban-Joe and Groy Eaglo

The Plcture of Alaska

Tinmu and the Tiger

Finders Keopers

Lost Dog, Jerry

Trees and Their Story

A Race for Bill

Biddy Christras

Ri de West into Denger

The Story of Serapina

This Boy Cody and His Friends 
FIImstrips Used in Fifth and Sixth Grades

I. Classroom Crafts

Clay modeling

Paper Sculpture

Puppets

Wire sculpturo

II. Communication

III. Conservation

Saving the Soll

Using our Forests Safely

IV. Scionce

We Leam about Weather

Understanding Weather Conditions

Changes in Weather

Balance Among Living Things

Seasong

A Home for Water Plants and Animals

V. Social Studies

The 011 Hunters

Drilling for oil

Petroleum Refining

VI. Transportation 
BI BLF OGRAP HY

\section{Books}

Beck, Robert H., Cook, Walter W., and Kearney, Nolan C. Curriculum in the Modern Elementary School. Now York: Prentice-Hall, Inc., 1953.

Burr, James B., Harding, Lowry W., 'and Jacobs, Leland B. Student Teaching in the Elementary Schools. New York: Appleton, Century Crofts, Inc., 1950. Charters, w. w., Motion Pictures and Youth. Now York: The Macmillan Company, 1933. Clapp, E. R., The Use of Resources in Education. New York: Harper and Brothers, 1952. Cox, Philip, Duff, John, and McNamara, Marle, Basic Principles of Guldance. New York: Prentice-Hell, Inc., 1948.

Dewey, John. Democracy and Education. New York: The Macmillan Company, 1917.

Dougherty, James H., Gorman, Frank H., and Phillips, Claude A. Elementary School Organt zation and Management. New York: The Macmillan Co., 1950. Everett, Samuol. The Community School. Now York:

D. Appleton-Century Co., 1938. 
Featherstone, Williom B. A Functional Curriculum for Youth. New York: American Book Co., 1950. Forman, Henry J. Our Movie Made children. Now York: The Macmillan Co., 1933.

Lee, Murrey J. and Lөe, Dorls M. The Child and His Curriculum. New York: Appletbn-Ćentury-Crofts, Ine., 1950.

Mahoney, John J. For Us the Living. An Approach to Civic Education. New York: Harper and Brothers, 1945.

Morgan, Joy E. The American Citizens Handbook. The National Educational Association of the U. S., Washington, 1941.

Michaelis, J. W. Social Studies for Children in a Democracy. New York: Prent1ce-Hall, 1950. Olsen, E. G. School and Community. New York: Prentice Hall, Inc., 1945.

Sait, Una B. New Horlzons for the Famlly. New York The Macmilian Co., 1938.

Schorling, Raleigh. Student Teaching. Now York: Mc Graw-H1 II Co., 1949. Shayen, Robert L. Television and our Children. New York: Longmans, Green and Co., 1951. 
Symonds, P. M. The Psychology of Parent-Child Relationships. New York: D. Appleton-Century Co., 1939. Commission on the English Curriculum of the National Council of Teachers of English. The English Language Arts. Now York: Appleton-Century-Crofts, Inc., 1952.

Willey, Roy D., and Young, Helen A. Radio in Elementary Education. Boston: D. C. Heath Co., 1948. Willoy, Roy D. Guidance in Elementary Education. New York: Harper Brothers, 1952.

\section{Pamphlets}

American Education Press. Teaching Current Events. 1947 .

Civic Education Foundation. It Has Been Done. New York: Comet Press Books, 1952. Civic Education Foundation. Maling Better Citizens.

A Program for Schools of America. New York. Federal Security Agency. Growing Into Democracy. Washington, D. C., Office of Education, 1951. Federal Social Security Adninistration. Your Child from 6 to 12 . No. $324,1949$. 
Jolnt Committeo on Health Problems in Education of the National Association and the American Modical Association. Mental Hygiene in the Classroom. 1951.

Metropolitan School Study Council. Education for Citizenship. Now York: 1949.

National Conforence of Christians and Jews. Builaing Brotherhood.

National Conference of Christians and Jews. Group

Processes in Intergroup Education.

National Conference of Christiens and Jews. Readings in Intergroup Relations.

The National Council for Soclal Studies. America's

Stalke in Human Rights. Washington, D. C.

National Education Association, 1949.

National Council for Social Studies. Improving

Human Relations. Washington, D. C., 1949.

The Junlor Town Meeting League. Learning Through

Group Discussion.

The Junior Town Meeting League. Maling Youth Discussion Conscious. 1948. 